\title{
Preparation of Magnetic Composites Based on Bulk Amorphous Iron Alloys
}

\section{BARTLOMIEJ JEŻ*, MARCIN NABIALEK, KINGA JEŻ}

Institute of Physics, Faculty of Production Engineering and Materials Technology, Czestochowa University of Technology, 19 Armii Krajowej Str., 42-200 Częstochowa, Poland

Iron-based amorphous alloys are characterized by so-called soft magnetic properties. Unfortunately, the geometry of iron-based amorphous materials significantly limits the applicability of these materials. One way to expand the use of these materials is to make composites based on them. As part of this work, rapid-cooled alloys were produced using the injection casting method. On their basis, magnetic composites with the addition of a non-magnetic binder were produced. The results of the structure (XRD) and magnetic properties (VSM) tests of the produced materials are presented. The research results have shown that the decisive impact on the magnetic properties of composites is the fact of the separation of magnetic particles with a non-magnetic binder. In this case, the influence of exchange interactions is dominated by dipole interactions.

Keywords: bulk amorphous alloys, soft magnetic composites, XRD, hysteresis loops

The so-called soft magnetic composites (SMCs) are a relatively new group of materials with high applicability. Magnetic composites are a response to difficulties in forming complicated shapes from other available materials exhibiting good magnetic properties, such as amorphous and nanocrystalline alloys [1,2]. Depending on the properties, magnetic composites are used as material for magnetic cores or wedges in nurseries of electric motors [3]. Composites exhibiting so-called good soft magnetic properties can be an alternative to Fe-Si sheets in the construction of low loss transformers [4]. There are various methods for producing these types of materials. One of the ways to obtain highquality composites is sintering and pressing ferromagnetic powders under high pressure, on the order of several hundred MPa [5-9]. However, obtaining such high pressure requires advanced technologies and is quite expensive. Magnetic composites can also be made on the basis of ferromagnetic amorphous powders. As it's know, good soft magnetic properties (i.e. high value of saturation magnetization and low coercive field value) are found in amorphous iron-based alloys [10-16]. Such materials are produced in the form of thin ribbons and films (so-called classic amorphous materials) and as volumetric alloys (bulk amorphous materials) [17]. Well-known methods for the production of bulk amorphous materials are injection or suction casting (cooling rate in the range of $10^{-1}-10^{3} \mathrm{~K} / \mathrm{s}$ ) [18-28]. Using the appropriate rules [29] when determining the chemical composition, it is possible to produce material with an amorphous structure at a relatively low cooling rate. Unfortunately, despite intensive research, amorphous materials are still not properly used. The reason for this is the difficulties in applying these materials due to their unsatisfactory geometry and dimensions. The creation of so-called bulk amorphous materials partly solved this problem, however, it seems that the appropriate development path for these materials is the production of composite materials based on ferromagnetic amorphous and nanocrystalline powders. One type of magnetic composites are ferromagnetic materials bonded with non-magnetic resins. Depending on the ratio of resin to powder, so-called dielectromagnetics and magnetodielectrics are distinguished. Dielectromagnetics contain up to $1 \%$ resin (mass) [30]. The resin serves to bond the ferromagnetic powder and isolate the particles. In order to obtain high density, high pressing pressure of up to several hundred MPa is used. Magnetodielectrics, on the other hand, have a resin content of $1 \%$ to $10 \%$ by mass [31]. The magnetic properties of these materials depend on a number of variables. They are influenced by production parameters such as pressure and pressing time. The magnetic and mechanical properties also depend on the amount and type of binder used as well as the fraction of the magnetic powder used [32].

The aim of the work was to produce magnetic composites based on a ferromagnetic amorphous alloy using the uniaxial pressing. Alloys as-quenched state and composites were tested for structure and magnetic properties.

\section{Research methodology}

The charge material with chemical composition $\mathrm{Fe}_{62} \mathrm{Co}_{9} \mathrm{Y}_{8} \mathrm{~W}_{1} \mathrm{~B}_{20}$ and $\mathrm{Fe}_{63} \mathrm{Co}_{8} \mathrm{Y}_{8} \mathrm{~W}_{1} \mathrm{~B}_{20}$ was produced in an arc furnace in a protective atmosphere of argon. Alloy components with a purity of $99.99 \%$ were weighed with an accuracy of 0.0001 gram. Polycrystalline ingots of 10 gram were produced. The melting temperature was controlled by changing the intensity of the current flowing through the electrode $(180$ - 380A). In order to homogenize the charge, the ingot was turned over using a manipulator each time before the remelting process. The batch was melted 7 times, each remelting preceded the melting of the titanium getter. The ingot was cleaned and divided into smaller pieces.

*email: bartek199.91@o2.pl 
Rapid-cooled alloys made using the injection casting method. The alloy was cast as $0.5 \mathrm{~mm}$ thick plates. The rapidcooling alloy production process was carried out in a protective atmosphere of argon. The material obtained in this way was subjected to tests of the structure and selected magnetic properties. The alloy was subjected to low energy crushing. The resulting ferromagnetic powder was used to produce magnetic composites. Using a set of laboratory sieves with a shaker, the ferromagnetic powder was divided into 20-200 $\mu \mathrm{m}$ fractions. Ferromagnetic powder was mixed with Duracyl Plus chemically hardenable resin $(0.5 \%$ resin by mass was used for each case). In the first step, magnetic powder was thoroughly mixed with the resin, then the material was mixed with the chemical hardener. The mixture prepared in this way was placed in a specially prepared form. The material was pressed under a pressure of $25 \mathrm{MPa}$ for 30 minutes. Figure 1 shows a scheme for producing magnetic composites using uniaxial pressing.

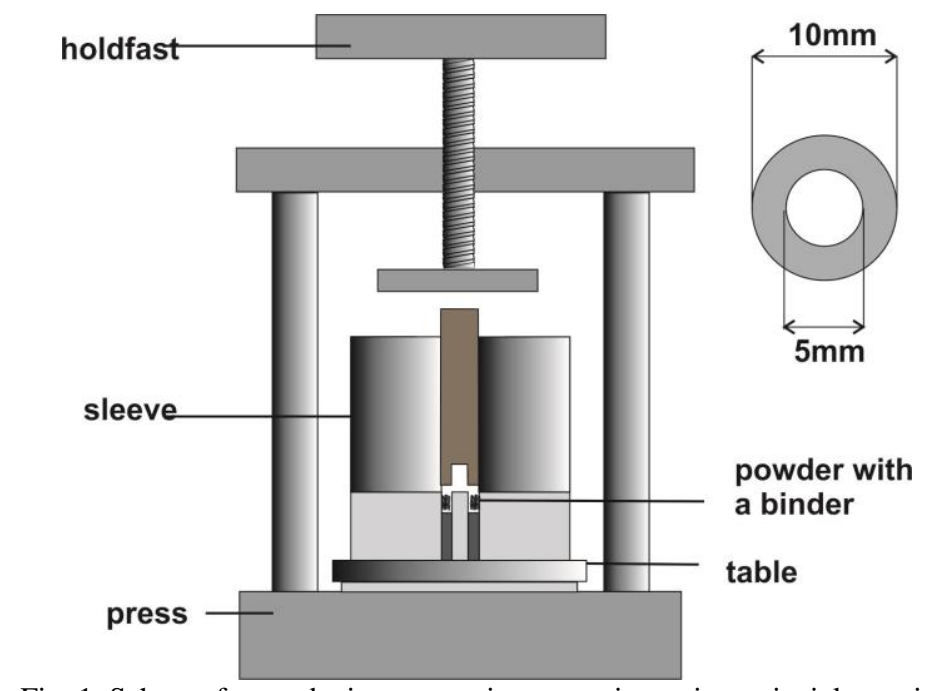

Magnetic composites in the form of toroids with an outer diameter of $10 \mathrm{~mm}$, an inner diameter of $5 \mathrm{~mm}$ and a thickness of $3 \mathrm{~mm}$ were produced (photo of samples in Figure 2).

a)
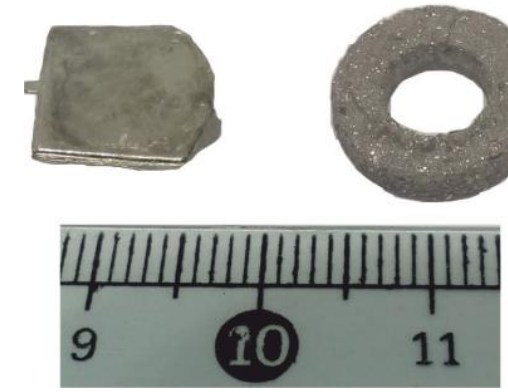

Fig. 2. Samples produced: a) alloy as-quenched state b) composite with $0.5 \%$ resin

Toroids were left for 24 hours to evaporate the rest of the hardener. The produced material was subjected to tests of the structure and selected magnetic properties.

The structure of the obtained materials was examined using the BRUCKER X-ray diffraction pattern. The test was carried out for the material after solidification and for produced composites. Magnetic properties were measured using a LakeShore vibrating magnetometer. Magnetization was measured in the field of induction of an external magnetic field up to $2 \mathrm{~T}$.

\section{Results and discussions}

Figure 3 contains X-ray diffraction images for the materials tested. 


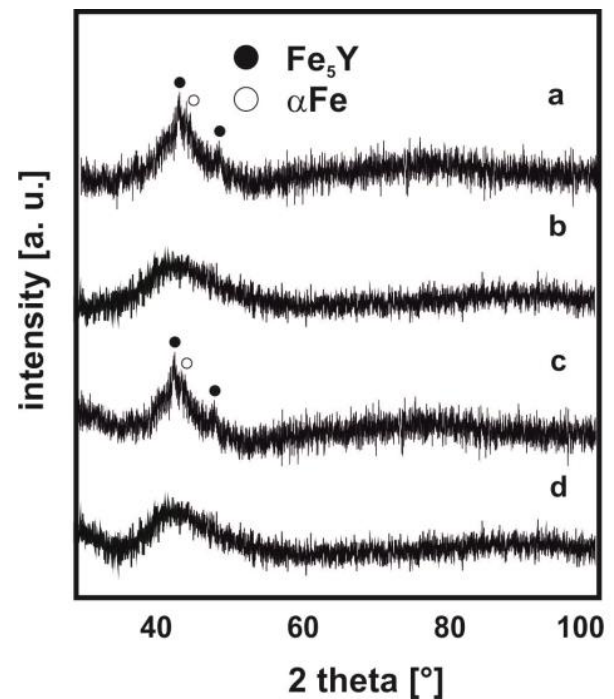

Fig. 3. X-ray diffraction images of the alloy as-quenched state: a) $\mathrm{Fe}_{62} \mathrm{Co}_{9} \mathrm{Y}_{8} \mathrm{~W}_{1} \mathrm{~B}_{20}$, b) $\mathrm{Fe}_{63} \mathrm{Co}_{8} \mathrm{Y}_{8} \mathrm{~W}_{1} \mathrm{~B}_{20}$ and composites based on alloys:

c) $\left.\mathrm{Fe}_{62} \mathrm{Co}_{9} \mathrm{Y}_{8} \mathrm{~W}_{1} \mathrm{~B}_{20}, \mathrm{~d}\right) \mathrm{Fe}_{63} \mathrm{Co}_{8} \mathrm{Y}_{8} \mathrm{~W}_{1} \mathrm{~B}_{20}$

Only wide maxima in the range $40-50^{\circ}$ of the two theta angle are visible on the diffractograms. $3 \mathrm{~b}$ and $3 \mathrm{~d}$ images are typical for amorphous materials. The maximum is related to the reflection of $\mathrm{X}$-rays from chaotically distributed atoms in the sample volume. In the case of the $\mathrm{Fe}_{63} \mathrm{Co}_{8} \mathrm{Y}_{8} \mathrm{~W}_{1} \mathrm{~B}_{20}$ alloy, two peaks appear indicating the presence of the crystalline phase. Based on the specialist program (Match!) magnetically semi-hard $\mathrm{Fe}_{5} \mathrm{Y}$ phase and soft magnetic $\alpha \mathrm{Fe}$ phase were identified. Diffractograms recorded for composites do not differ from images corresponding to alloys asquenched state. Figure 3 contains magnetic saturation polarization curves as a function of temperature.

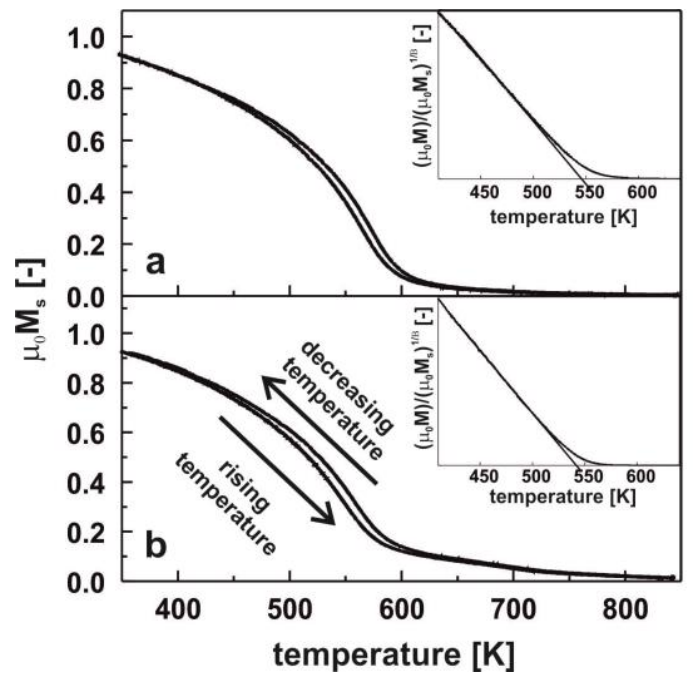

Fig. 4. Magnetic saturation polarization curves as a function of temperature for an alloy as-quenched state: a) $\mathrm{Fe}_{62} \mathrm{Co}_{9} \mathrm{Y}_{8} \mathrm{~W}_{1} \mathrm{~B}_{20}$, b) $\mathrm{Fe}_{63} \mathrm{Co}_{8} \mathrm{Y}_{8} \mathrm{~W}_{1} \mathrm{~B}_{20}$

One mild inflection is visible on the recorded curves. It is associated with the transition of the magnetic phase from ferro to paramagnetic. No additional transitions means that in the tested temperature range, no other magnetic phases occur in the sample volume. The return curve has a similar course to the original curves. The higher value of magnetic polarization of saturation on the return curves is associated with the relaxations that occurred during sample heating. Based on the critical factor $\beta=0.36$ according to Heisenberg's assumptions, the Curie temperature for the examined alloys was determined (549K for the $\mathrm{Fe}_{62} \mathrm{Co}_{9} \mathrm{Y}_{8} \mathrm{~W}_{1} \mathrm{~B}_{20}$ alloy and $541 \mathrm{~K} \mathrm{Fe}_{63} \mathrm{Co}_{8} \mathrm{Y}_{8} \mathrm{~W}_{1} \mathrm{~B}_{20}$ ). Figure 5 contains static magnetic hysteresis loops for the materials tested. 


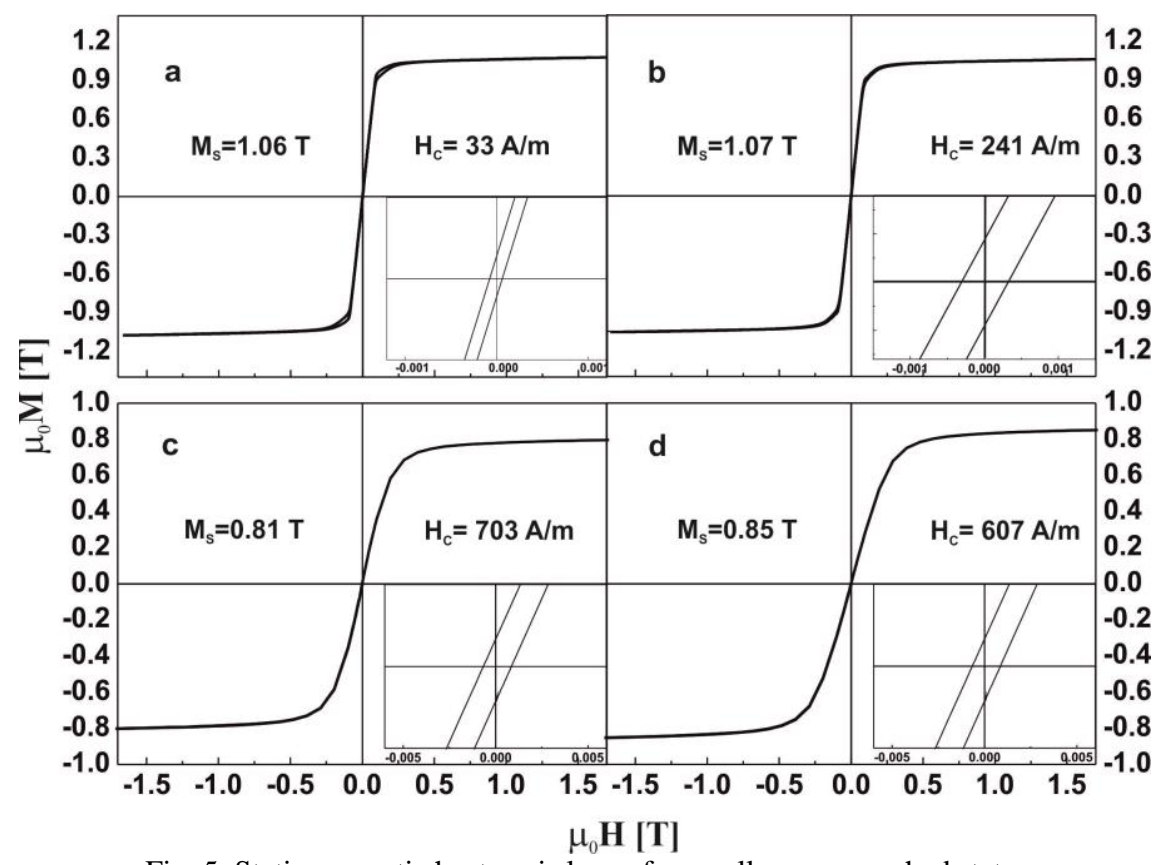

Fig. 5. Static magnetic hysteresis loops for an alloy as-quenched state: a) $\mathrm{Fe}_{62} \mathrm{Co}_{9} \mathrm{Y}_{8} \mathrm{~W}_{1} \mathrm{~B}_{20}$, b) $\mathrm{Fe}_{63} \mathrm{Co}_{8} \mathrm{Y}_{8} \mathrm{~W}_{1} \mathrm{~B}_{20}$ and composites based on alloys:

c) $\mathrm{Fe}_{62} \mathrm{Co}_{9} \mathrm{Y}_{8} \mathrm{~W}_{1} \mathrm{~B}_{20}$, d) $\mathrm{Fe}_{63} \mathrm{Co}_{8} \mathrm{Y}_{8} \mathrm{~W}_{1} \mathrm{~B}_{20}$

The $\mathrm{Fe}_{62} \mathrm{Co}_{9} \mathrm{Y}_{8} \mathrm{~W}_{1} \mathrm{~B}_{20}$ alloy as-quenched state has good soft magnetic properties, i.e. saturation magnetization $1.06 \mathrm{~T}$ and a coercive field value of $33 \mathrm{~A} / \mathrm{m}$. The $\mathrm{Fe}_{63} \mathrm{Co}_{8} \mathrm{Y}_{8} \mathrm{~W}_{1} \mathrm{~B}_{20}$ alloy has similar saturation magnetization and a coercive field value over 7 times higher. Better magnetic properties of $\mathrm{Fe}_{62} \mathrm{Co}_{9} \mathrm{Y}_{8} \mathrm{~W}_{1} \mathrm{~B}_{20}$ alloy should be combined with the presence of fine grains of crystalline phases. The presence of grains with dimensions of several nanometers reduces the coercive field value [33]. It can be expected that the composite based on $\mathrm{Fe}_{63} \mathrm{Co}_{8} \mathrm{Y}_{8} \mathrm{~W}_{1} \mathrm{~B}_{20}$ alloy will have worse properties than the composite based on $\mathrm{Fe}_{62} \mathrm{Co}_{9} \mathrm{Y}_{8} \mathrm{~W}_{1} \mathrm{~B}_{20}$ alloy. However, the results obtained do not confirm this. In the case of the $\mathrm{Fe}_{63} \mathrm{Co}_{8} \mathrm{Y}_{8} \mathrm{~W}_{1} \mathrm{~B}_{20}$ alloy, $0.5 \%$ resin addition increased the coercive field by 2.5 -fold, while for the $\mathrm{Fe}_{62} \mathrm{Co}_{9} \mathrm{Y}_{8} \mathrm{~W}_{1} \mathrm{~B}_{20}$ alloy the value increased 20 times. This means that already a $0.5 \%$ addition (by mass) of resin separates magnetic particles to such an extent that exchange interactions do not significantly affect the value of the coercive field. Dipole interactions and the distribution and probably the size of magnetic particles in the volume of the composite have a greater impact on shaping magnetic properties.

\section{Conclusions}

Magnetic composites based on bulk amorphous alloys on an iron basis are used in many branches of electronics and electrical engineering. This work shows that it is possible to produce these types of materials using a simple uniaxial press and a relatively low compression pressure. It is worth adding that the composites were made with only a small proportion of non-magnetic binder. Composites were made of alloys differing significantly in the coercive field value. However, the properties of the composites themselves are very similar. This is due to the separation of magnetic powder particles with a non-magnetic binder. This separation weakens exchange interactions, magnetic properties are determined by the arrangement of magnetic particles, their size and degree of separation.

\section{References}

1.MCHENRY, M. E., WILlARD, M. A., LAUGHLIN, D. E., Progress in Materials Science, 44, 1999, p. 291.

2.HERZER, G., Acta Materialia, 61, 2013, p. 718.

3.AZAREWICZ, S., WĘGLIŃSKI, B., Problem Notebooks - Electric Machines, 77, 2007, p. 87 (in Polish).

4.BRZÓZKA, K., ŚLAWSKA-WANIEWSKA, A., NOWICKI, P., JEZUITA, K., Material Science and Engineering A, 226-228, 1997, p. 654.

5.TAGHVAEI, A.H., SHOKROLLAHI, H., GHAFFARI, M., JANGHORBAN, K., Journal of Physics and Chemistry of Solids, 71,2010, p. 7.

6.PENG, Y., YI, Y., LI, L., AI, H., WANG, X., CHEN, L., Journal of Magnetism and Magnetic Materials, 428, 2017 , p. 148.

7.LI, X., DONG, Y., LIU, M., CHANG, C., WANG, X., Journal of Alloys and Compounds, 696, 2017, p. 1323.

8.FÜZER, J., STRECKOVA, M., DOBAK, S., DAKOVA, L., KOLLAR, P., FABEROVA, M., BURES, R., OSADCHUK, Y., KUREK, P., VOJTKO, M., Journal of Alloys and Compounds, 753, 2018, p. 219.

9.XIA, C., PENG, Y., YI, Y., DENG, H., ZHU, Y., HU, G., Journal of Magnetism and Magnetic Materials, 474, 2019 , p. 424.

10.BŁOCH, K., Rev. Chim (Bucharest), 68, no. 10, 2017, p. 2413.

11.BŁOCH, K., Rev. Chim (Bucharest), 69, no. 4, 2018, p. 982.

12.ZHANG, Y., WANG, Y., MAKINO, A., AIP ADVANCES, 8, 2018, 047703.

13.LI, W., YANG, Y.Z., XU, J., Journal of Non-Crystalline Solids, 461, 2017, p. 93.

14.DONG, C., INOUE, A., WANG, X.H., KONG, F.L., ZANAEVA, E.N., WANG, F., BAZLOV, A.I., ZHU, S.L., LI, Q., Journal of NonCrystalline Solids, 500, 2018, p. 173. 
15.WANG, F., INOUE, A., HAN, Y., KONG, F.L., ZHU, S.L., SHALAAN, E., AL-MARZOUKI, F., OBAID, A., Journal of Alloys and Compounds, 711, 2017, 132.

16.DOU, L., LIU, H., HOU, L., XUE, L., YANG, W., ZHAO, Y., CHANG, C., SHEN, B., Journal of Magnetism and Magnetic Materials, 358359, 2014, p. 23.

17.NABIAŁEK, M., GARUS, S., Acta Physica Polonica A, 130, 2016, p. 1010-1012.

18.WANG, W.H., DONG, C., SHEK, C.H., Materials Science and Engineering R, 44, 2004, p. 45.

19.NABIAŁEK, M., Journal of Alloys and Compounds, 642, 2015, p. 98.

20.SI, J., DU, C., WANG, T., WU, Y., WANG, R., HUI, X., Journal of Alloys and Compounds 741, 2018, p. 542.

21.NARAYAN, R.L., SINGH, P.S., HOFMANN, D.C., HUTCHINSON, N., FLORES, K.M., RAMAMURTY, U., Acta Materialia, 60, 2012 , p. 5089.

22.TREXLER, M.M., THADHANI, N.N., Progress in Materials Science, 55, 2010, p. 759.

23.ISHIDA, M., TAKEDA, H., WATANABE, D., AMIYA, K., NISHIYAMA, N., KITA, K., SAOTOME, Y., INOUE, A., Materials Transactions, 45, 2004, p. 1239.

24.NABIALEK, M., JEZ, B., European Journal of Materials Science and Engineering, 2, no. 1, 2017, p. 33.

25.BLOCH, K., TITU, M.A., SANDU, A.V., Rev. Chim (Bucharest), 68. no. 9, 2017, p. 2162.

26.NABIALEK, M., JEZ, B., European Journal of Materials Science and Engineering, 4, no. 3, 2019, p. 121.

27.NABIALEK, M., JEZ, K., European Journal of Materials Science and Engineering, 4, no. 1, 2019, p. 23.

28.JEZ, K., European Journal of Materials Science and Engineering, 3, no. 1, 2018, p. 3.

29.INOUE, A., Acta Materialia, 48, 2000, p. 279.

30.JANTA, T., Scientific papers of the institute of electrical machines, drives and measurements of the Wrockaw University of Science and Technology, 65, 2011, p. 139 (in Polish).

31.GAWORSKA, D., WĘGLIŃSKI, B., SZAFRAN, M., WIŚNIEWSKI, P., Composites, 5, 2005, p. 46.

32.BUKOWSKA, A., SZOTA, M., NABIAŁEK, M., BŁOCH, K., ŁUKASZEWICZ, A., KLIMAS, J., Archives of Materials Science and Engineering, 68/2, 2014, p. 59.

33.T. KULIK, Soft magnetic nanocrystalline materials obtained by crystallization of metallic glasses, Warsaw University of Technology publishing house, Warsaw 1998 (in Polish).

$\overline{\text { Manuscript received: } 26.11 .2019}$ 